\title{
Pore-fluid Fe isotopes reflect the extent of benthic Fe redox recycling: Evidence from continental shelf and deep-sea sediments
}

\author{
W.B. Homoky ${ }^{1, *}$, S. Severmann², R.A. Mills ${ }^{1}$, P.J. Statham ${ }^{1}$, and G.R. Fones ${ }^{3}$ \\ ${ }^{1}$ National Oceanography Centre, University of Southampton, Southampton SO14 3ZH, UK \\ 2Department of Earth and Planetary Sciences, and Institute of Marine and Coastal Sciences, Rutgers University, New Brunswick, \\ New Jersey 08901, USA \\ ${ }^{3}$ School of Earth and Environmental Sciences, University of Portsmouth, Portsmouth PO1 3QL, UK
}

\begin{abstract}
Pore-fluid Fe isotopes may be a unique tracer of sediment respiration by dissimilatory Fereducing bacteria, but to date, pore-fluid Fe isotope measurements have been restricted to continental shelf settings. Here, we present $\delta^{56} \mathrm{Fe}$ values of pore fluids from two distinct sedimentary settings: (1) a riverine-dominated site on the northern California margin (Eel River shelf; $120 \mathrm{~m}$ water depth) and (2) biogenic opal-rich volcaniclastic deep-sea sediments from the Southern Ocean (north and south of the Crozet Plateau; 3000-4000 m water depth). The Fe isotope compositions of Crozet region pore fluids are significantly less fractionated $\left(\delta^{56} \mathbf{F e}=\right.$ $+0.12 \%$ to $-\mathbf{0 . 0 1 \%} \%)$ than the Eel River shelf $\left(\delta^{56} \mathrm{Fe}=-\mathbf{0 . 6 5} \%\right.$ o to $-3.40 \%$ ) and previous studies of pore-fluid Fe isotopes, relative to average igneous rocks. Our data represent the first measurements of $\mathrm{Fe}$ isotope compositions in pore fluids from deep-sea sediments. A comparison of pore-fluid $\delta^{56} \mathrm{Fe}$ with the relative abundance of highly labile $\mathrm{Fe}$ in the reactive sedimentary $\mathrm{Fe}$ pool demonstrates that the composition of Fe isotopes in the pore fluids reflects the different extent of sedimentary $\mathrm{Fe}$ redox recycling between these sites.
\end{abstract}

\section{INTRODUCTION}

Iron is an essential micronutrient for intracellular processes, and in many macronutrientreplete oceanic regions (high nutrient, low chlorophyll [HNLC]), primary production is limited by the availability of Fe (Martin, 1990). Consequently, the supply of Fe to HNLC regions has been proposed as a major contributing factor to the regulation of carbon drawdown on glacial to interglacial time scales (Martin et al., 1990). Much of the Fe input in HNLC regions has commonly been attributed to aerosol deposition and dissolution, but, increasingly, studies highlight the potential importance of sedimentary Fe sources for the coastal, and even open, ocean (Lam et al., 2006; Nishioka et al., 2007). In continental margin sedimentary settings, the benthic transport of dissolved $\mathrm{Fe}$ has been found to be significant (McManus et al., 1997; Berelson et al., 2003; Elrod et al., 2004), and enrichment of $\mathrm{Fe}$ in the pore fluids and bottom waters is driven by the reductive dissolution of Fe during organic carbon decomposition.

Iron isotopes have emerged as a new tool to evaluate iron cycling in aquatic environments (Anbar and Rouxel, 2007; Johnson et al., 2008). Incubation experiments have demonstrated that the reduction of $\mathrm{Fe}(\mathrm{III})$ in the presence of dissimilatory Fe-reducing bacteria produces aqueous $\mathrm{Fe}^{2+}$ with $\delta^{56} \mathrm{Fe}$ values that are $0.5 \%-2 \%$ lower than the initial Fe(III) substrate (Beard et al., 1999; Icopini et al., 2004; Crosby et al., 2007). Pore fluids from sediments where organic matter oxidation pro-

*E-mail: wbh@noc.soton.ac.uk. ceeds through significant microbial $\mathrm{Fe}$ reduction yield isotope compositions for dissolved $\mathrm{Fe}^{2+}$ that are $\sim 1 \%$ o-3\%o lighter than average igneous rocks, suggesting that benthic $\mathrm{Fe}$ inputs to the ocean may carry a unique isotopic fingerprint (Severmann et al., 2006).

Dissimilatory iron reduction (DIR) is a form of chemolithotrophy that is widespread during diagenesis of marine sediments, and the rate of this process is controlled by organic carbon oxidation and the availability of Fe(III) substrates (Froelich et al., 1979). DIR was one of the earliest metabolic pathways to evolve on Earth (Vargas et al., 1998), and it has been suggested that sedimentary Fe isotopes may be used to reconstruct past Fe cycling in the Archean ocean (Rouxel et al., 2005; Yamaguchi et al., 2005; Severmann et al., 2008).

Pore-fluid Fe isotope measurements have so far been restricted to the continental shelves where DIR is extensive (Bergquist and Boyle, 2006; Severmann et al., 2006). There have been no measurements of Fe isotopes in loworganic-carbon, suboxic sediment pore fluids, in deep-water settings where sediment accumulation rates are much slower and oxygen penetration is deeper than on the continental shelves, or in sediments where abiotic processes such as adsorption or ligand complexation may significantly imprint the pore-fluid Fe isotope composition. The need for comparison of Fe isotopes in shallow- and deep-water environments has been identified (Johnson et al., 2008), and characterization of the Fe isotopic fingerprint of DIR in natural, complex aqueous systems is important for the effective interpretation of the sedimentary record, and for developing the potential utility of Fe isotopes as a tracer of benthic Fe fluxes.

We present here new $\delta^{56} \mathrm{Fe}$ data for surface sediment pore fluids $(0-25 \mathrm{cmbsf}$ [centimeters below seafloor]) from two distinct sedimentary settings: (1) a riverine-dominated site on the northern California margin (Eel River shelf; $120 \mathrm{~m}$ water depth), where the organic carbon accumulation rate is high $\left(\sim 26.7 \mathrm{~g} \mathrm{C} \mathrm{m}^{-2} \mathrm{a}^{-1}\right.$; Sommerfield and Nittrouer, 1999) and carbon remineralization is driven by extensive Fe redox cycling, and (2) mixed biogenic opal-rich volcaniclastic sediments from two deep-sea sites in the Southern Ocean (M6: 4222 m; and M10: $3227 \mathrm{~m}$ ), where organic carbon accumulation rates are low (M6: $\sim 0.011 \mathrm{~g} \mathrm{C} \mathrm{m}^{-2} \mathrm{a}^{-1}$; M10: $\sim 0.113 \mathrm{~g} \mathrm{C} \mathrm{m}^{-2} \mathrm{a}^{-1}$ ) and diagenetic Fe cycling is limited by the availability of reactive organic carbon (see the GSA Data Repository ${ }^{1}$ for additional sample site information).

\section{RESULTS}

Pore-fluid nitrate penetration depth provides a qualitative tool for comparing the sedimentary redox status of our study sites. This depth is greatest at the Southern Ocean site (M6; 20-30 cmbsf), intermediate at the Southern Ocean northern site (M10; $10 \mathrm{cmbsf}$ ), and shallowest at the Eel River shelf site $(\sim 5 \mathrm{cmbsf})$ (Fig. 1A). The shallowest nitrate penetration depth occurs at the site of highest mean organic carbon content at the Eel River shelf $(0.87 \%, 0-22$ cmbsf), which also has the greatest proportion of highly labile $\mathrm{Fe}$ phases $\left(\mathrm{Fe}_{\mathrm{h} \text {-lab }}\right)$ relative to reactive hydrous $\mathrm{Fe}$ oxide (HFO) substrates $\left(\mathrm{Fe}_{\mathrm{h}-\mathrm{lab}} /\left[\mathrm{Fe}_{\mathrm{h}-\mathrm{lab}}+\mathrm{HFO}\right]=0.63-0.69\right.$ for Eel River compared to 0.02-0.20 in Crozet sediments; see Table DR1 in the Data Repository). The relative proportions of $\mathrm{Fe}_{\mathrm{h}-\mathrm{lab}}$ (Na acetate leachable) and $\mathrm{HFO}$ (hydroxylamine-HCl leachable) were estimated using the sequential sediment extrac-

${ }^{1}$ GSA Data Repository item 2009180, full description of materials and methods (including sample site descriptions, sampling and analytical procedures, justification of Rhizone sampling for pore-fluid nutrients, and critical evaluation of Crozet region porefluid Fe concentrations), is available online at www. geosociety.org/pubs/ft2009.htm, or on request from editing@geosociety.org or Documents Secretary, GSA, P.O. Box 9140, Boulder, CO 80301, USA. 
A $\quad \mathrm{NO}_{3}{ }^{-}(\mu \mathrm{M}) \quad \operatorname{Org} \mathrm{C}(\mathrm{wt} \%) \quad \mathrm{Fe}_{\mathrm{h}-\mathrm{lab}} /\left(\mathrm{HFO}+\mathrm{Fe}_{\mathrm{h}-\mathrm{lab}}\right)$ $\mathrm{NO}_{3}{ }^{-}(\mu \mathrm{M}) \quad \operatorname{Org~C}(\mathrm{wt} \%) \mathrm{Fe}_{\mathrm{h}-\mathrm{ab}} /\left(\mathrm{HFO}+\mathrm{Fe}_{\mathrm{h}-\mathrm{lab}}\right)$

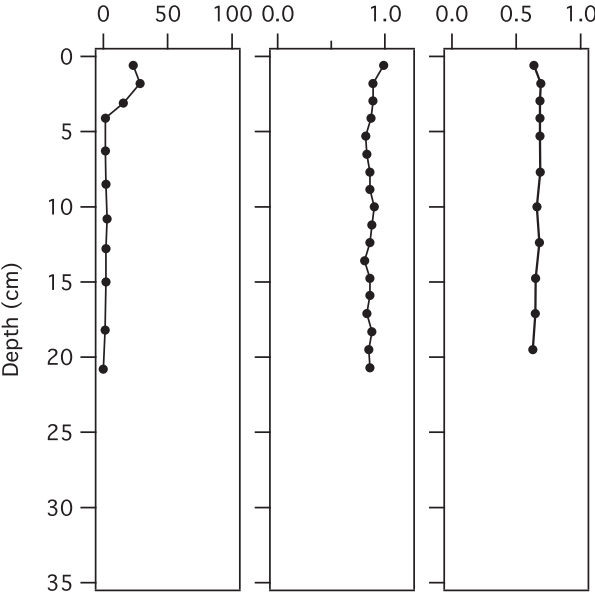

Eel River shelf

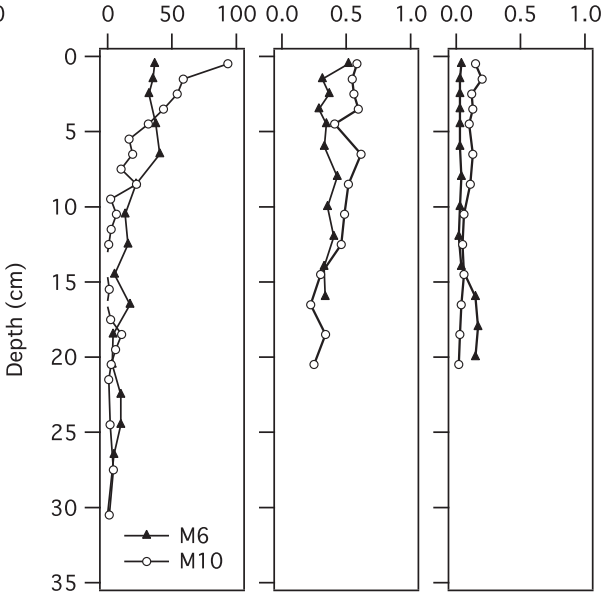

Crozet region

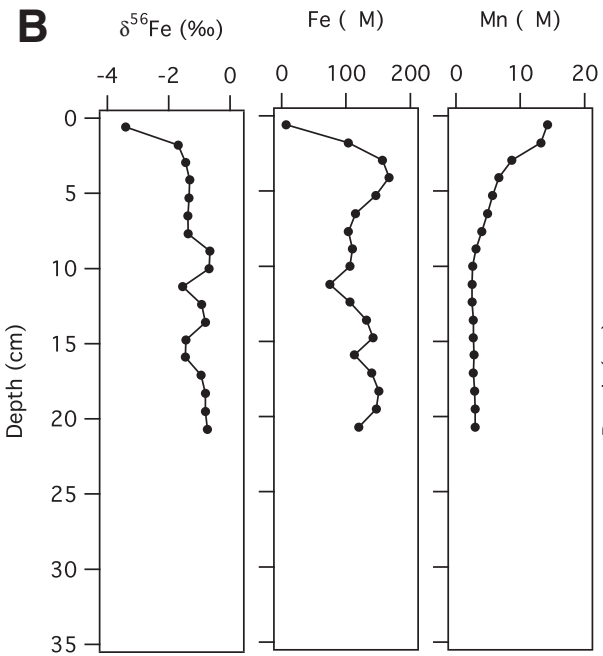

Eel River shelf
20

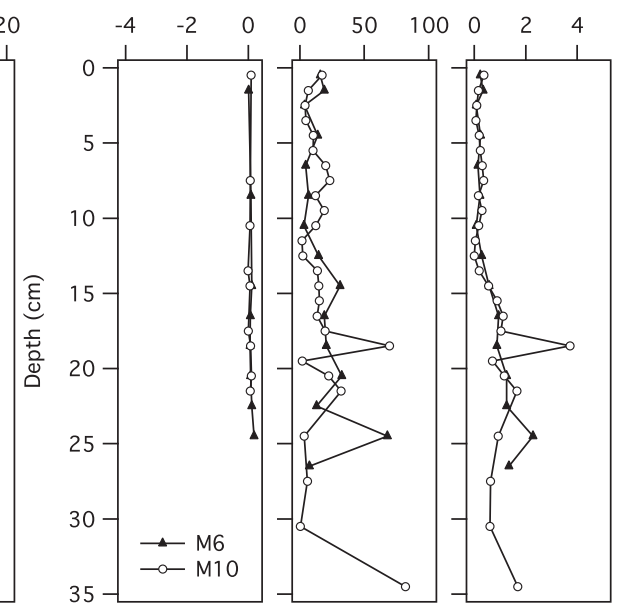

Crozet region

Figure 1. A: Pore-fluid nitrate, solid-phase organic carbon, and the proportion of highly labile $\mathrm{Fe}\left(\mathrm{Fe}_{\mathrm{h}}\right)$ relative to hydrous Fe oxide (HFO) profiles. Nitrate penetration depth provides a qualitative tool to assess the redox conditions of the study sites. The $\mathrm{Fe}_{\mathrm{h}-\mathrm{lab}} /\left(\mathrm{HFO}+\mathrm{Fe}_{\mathrm{h}-\mathrm{lab}}\right)$ ratio records the relative proportion of highly labile $\mathrm{Fe}$ in a reactive $\mathrm{Fe}$ pool utilized during dissimilatory iron reduction (DIR). B: Concentration of $\mathrm{Fe}, \mathrm{Mn}$, and $\delta^{56} \mathrm{Fe}$ in Crozet region and Eel River shelf pore fluids.

tion procedure given in Poulton and Canfield (2005) (see the Data Repository for details of all methods and analyses). The ratio $\mathrm{Fe}_{\mathrm{h}-\mathrm{lab}} /\left(\mathrm{Fe}_{\mathrm{h}-\mathrm{lab}}+\right.$ HFO) provides an estimate of the extent of diagenetic redox recycling of $\mathrm{Fe}$.

Crozet region pore-fluid $\delta^{56} \mathrm{Fe}$ values range between $+0.12 \%$ and $-0.01 \%$ o relative to average igneous rocks (Fig. 1B) and closely resemble those of average continental weathering products $(0.2 \%$ $\pm 0.7 \%$; Beard et al., 2003). In contrast to both these sites, Eel River shelf $\delta^{56} \mathrm{Fe}$ pore-fluid values lie between $-0.65 \%$ o and $-3.40 \%$, and the greatest isotopic fractionation is closest to the sediment-seawater interface (Fig. 1B). Crozet pore-fluid Fe concentrations are $\sim 1-80 \mu \mathrm{M}$ at M10 and M6, and they are characterized by similar Mn distributions (up to $4 \mu \mathrm{M}$ ), with maxima at $\sim 17$ and 25 cmbsf at M10 and M6, respectively. At the Eel River shelf site, pore-fluid Fe concentrations reach a subsurface maximum of $167 \mu \mathrm{M}$ at 5 cmbsf, and Mn concentrations are highest (14 $\mu \mathrm{M}$ ) in the upper 0-5 cmbsf (see Data Repository Table DR2).

\section{DISCUSSION}

The distributions of Fe and Mn in Eel River shelf pore fluids are broadly consistent with the biogeochemical zonation of respiratory processes (Froelich et al., 1979), indicating the transition from aerobic respiration through to DIR between 0 and 5 cmbsf. However, Fe and Mn values in Crozet region pore fluids are not typical of deep-sea profiles, and values are relatively high (1-20 $\mu \mathrm{M} \mathrm{Fe}$; $0.1-0.3 \mu \mathrm{M} \mathrm{Mn})$ in the upper $10 \mathrm{~cm}$ compared with previous mea- surements from deep-sea Southern Ocean sites $(<0.1 \mu \mathrm{M}$ Fe; King et al., 2000); the equatorial Pacific ( $<5 \mu \mathrm{M}$ Fe; Haeckel et al., 2001); tropical northeast Atlantic (1-13 $\mu \mathrm{M}$ Fe; Froelich et al., 1979); and many coastal shelf settings (Canfield et al., 1993; McManus et al., 1997). Additionally, the biogeochemical zonation of $\mathrm{NO}_{3}^{-}, \mathrm{Mn}$, and $\mathrm{Fe}$ in the Crozet region pore fluids is less apparent than at the Eel River shelf site and provides little evidence for DIR-dominated diagenesis.

An analysis of two different dissolved size fractions $(0.2 \mu \mathrm{m}$ and $0.02 \mu \mathrm{m}$; see the Data Repository) in Crozet region pore fluids demonstrates that significant colloidal and/ or nanoparticulate (herein after "colloidal") phases are present (Fig. 2). We speculate that these colloids are composed of adsorbed and/ or organic ligand-bound $\mathrm{Fe}^{2+} / \mathrm{Fe}^{3+}$ that may be utilized during DIR along with nanoparticulate basaltic weathering products. We suggest that the distribution of colloidal phases in the pore fluids is influenced by the episodic supply of organic carbon, which disrupts the steady-state pore-fluid composition (Gehlen et al., 1997); the vertical mixing of volcaniclastic sediments through slumping and turbidite emplacement in this region (Marsh et al., 2007); the influence of bioirrigation and bioturbation (Aller, 1990); and the uncertain role of stabilizing organic complexes in the pore-fluid environment (Luther et al., 1992).

Eel River shelf pore-fluid $\delta^{56} \mathrm{Fe}$ compositions are consistent with previous studies of $\mathrm{Fe}$ reducing continental margin sediments where DIR catalyzes the fractionation of Fe isotopes
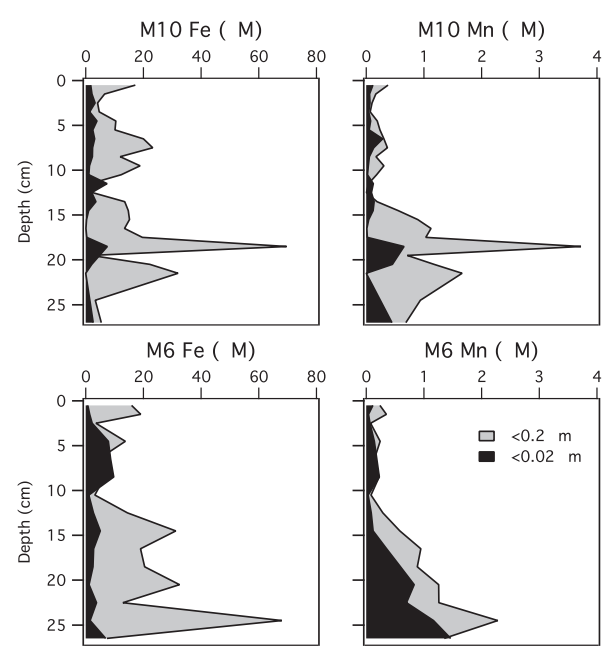

Figure 2. Pore-fluid Fe and Mn concentration at M10 and M6 sampled sequentially by two different filter sizes. Pore-fluid $\mathrm{Fe}$ and $\mathrm{Mn}$ are partitioned between $<0.2$ to $>0.02 \mu \mathrm{m}$, and $<0.02 \mu \mathrm{m}$ size fractions at these sites, and they are inferred to make up a significant colloidal and/or nanoparticulate component of the pore fluids. 
during redox cycling (Severmann et al., 2006) (Fig. 3). Crozet region pore-fluid $\delta^{56} \mathrm{Fe}$ values are significantly less fractionated than previous values reported for suboxic pore fluids (Fig. 3). Severmann et al. (2006) noted that nearzero $\delta^{56} \mathrm{Fe}$ values for pore fluids might reflect equilibrium with $\mathrm{FeS}$. There is no evidence for sulfide diagenesis in Crozet region Holocene sediments (Marsh et al., 2007). Therefore, the comparison of the Eel River shelf and Crozet region suggests that either a mechanism other than DIR is releasing a substantial amount of $\mathrm{Fe}$ (up to $80 \mu \mathrm{M} ; \delta^{56} \mathrm{Fe} \sim 0.0 \%$ ) into the Crozet pore fluids, or that DIR alone may be insufficient to generate the low $\delta^{56} \mathrm{Fe}$ values we observe in continental margin sediments.

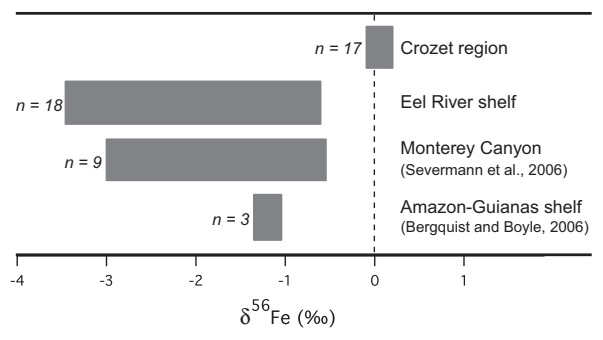

Figure 3. Comparison of Crozet region and Eel River shelf pore-fluid $\mathrm{Fe}$ isotope compositions with published data from dissimilatory iron reduction (DIR)-dominated reducing sediments on continental shelves.

Experiments have shown that $\mathrm{Fe}$ isotope fractionations of $>1 \%$ in aqueous systems can also be produced by abiotic processes. For example, ligand-promoted dissolution of mineral substrates, such as goethite, ferrihydrite, and hornblende (Brantley et al., 2004), abiotic sorption and surface exchange (Icopini et al., 2004; Crosby et al., 2007), and isotope exchange between free and organically or inorganically complexed Fe (Dideriksen et al., 2008) could potentially contribute to variations in isotope compositions in nature that are indistinguishable from biological fractionations. Deconvolution of these processes in nature presents a major challenge; however, it has been argued that abiotic processes alone cannot generate the large inventories of isotopically fractionated $\mathrm{Fe}$ that have been identified in continental margin sediments (Johnson et al., 2008). We hypothesize that the observed variation in $\mathrm{Fe}$ isotope composition between our study sites reflects differences in the extent of biogenic benthic recycling of the reactive $\mathrm{Fe}$ pool.

The sedimentary reduction and oxidation of Fe during early diagenetic redox recycling has been estimated to occur 100-300 times prior to ultimate burial below the redoxcline (Canfield et al., 1993), where the extent of bioturbation and bioirrigation may enhance the redox recycling of $\mathrm{Fe}$ substrates by oxidizing $\mathrm{Fe}^{2+}$ and suppressing the onset of sulfide diagenesis (Canfield et al., 1993). The composition of Fe isotopes in sediment pore fluids is inferred to reflect the extent of redox recycling of Fe between DIR-derived $\mathrm{Fe}^{2+}$ aq and highly labile oxidation products, such as amorphous Fe-(oxyhdr)oxide (Severmann et al., 2008). Experimental investigations of the mechanism producing $\mathrm{Fe}$ isotope fractionation during DIR have shown that the generation of light dissolved $\mathrm{Fe}^{2+}{ }_{\text {aq }}$ can be attributed to a coupled electron and isotope exchange between sorbed $\mathrm{Fe}^{2+}$ and a reactive ferric $\mathrm{Fe}$ component on the surface of the Fe-oxide that is open to isotope exchange (Crosby et al., 2007). These authors argue that changes in the absolute $\delta^{56} \mathrm{Fe}$ values of $\mathrm{Fe}^{2+}{ }_{\text {aq }}$ in their experiments reflect changes in the relative sizes of the reactive $\mathrm{Fe}$ pools. The reactivity of $\mathrm{Fe}$-oxide minerals may therefore be the primary control on the porefluid $\mathrm{Fe}$ isotope composition. Although we did not quantify the reactive $\mathrm{Fe}$ (III) component in the ferric oxide surfaces directly, the coincidence of low pore-fluid $\delta^{56} \mathrm{Fe}$ values with high $\mathrm{Fe}_{\text {h-lab }}$ ' $\left(\mathrm{Fe}_{\mathrm{h}-\mathrm{lab}}+\mathrm{HFO}\right)$ in sediments from the Eel River shelf is consistent with the continuous reoxidation of $\mathrm{Fe}^{2+}{ }_{\text {aq }}$ to amorphous $\mathrm{Fe}$-(oxyhydr)oxides, providing an abundance of surface sites for isotope exchange, which are lacking in the Crozet sediments (Fig. 4).

We interpret the organic carbon supply to the Eel River shelf to be sufficient to sustain DIR and the redox recycling of $\mathrm{Fe}$, thereby enriching highly labile $\mathrm{Fe}$ phases in the reactive $\mathrm{Fe}$ pool and accounting for the highest pore-fluid Fe isotope fractionation. In contrast, the low organic carbon input to the deep Crozet region sediments limits DIR and redox recycling of Fe. We speculate that highly seasonal organic carbon inputs to M10 (Pollard et al., 2009) may promote the episodic contribution of DIR to sediment respiration and account for the relative enrichment of highly labile Fe in M10 surface sediments and in M6 turbidite layers. In these circumstances, processes that contribute to the generation of colloids and/or nanoparticulates in the pore fluids (van der Zee et al., 2003) are likely to have near crustal isotope compositions and dilute the isotopic signature of DIR.

\section{CONCLUSIONS}

High dissolved Fe pore-fluid contents indicate suppression of sulfide diagenesis in Eel River shelf sediments and volcaniclastic weathering in Southern Ocean sediments. We demonstrate that the pore-fluid $\mathrm{Fe}$ isotope compositions reflect the extent of $\mathrm{Fe}$ recycling during early diagenesis, which is driven by supply of reactive organic carbon and $\mathrm{Fe}$. We invite future interpretations of the rock record to consider the importance of Fe isotope processing in carbonlimited environments. Additionally, the unique isotopic fingerprint of pore-fluid $\mathrm{Fe}$ in continental shelf settings is confirmed, drawing further attention to the potential utility of $\mathrm{Fe}$ isotopes as a tracer of shelf-derived Fe inputs to seawater.

\section{ACKNOWLEDGMENTS}

This work was supported by the UK Natural Environment Research Council grant NE/B502844/1. California margin sampling and isotopic analyses were supported by the U.S. National Science Foundation grant OCE-0624777 (James McManus) and OCE-0624704 (Severmann), and our thanks go to the crew of RV Wecoma cruise WE0704E. We thank the crews of RRS Discovery cruises D286 and D300, as well as D. Green, P. Morris, S. Taylor, and L. Hep-
Figure 4. Comparison of Eel River shelf (ER) and Crozet region (M10 and M6) sediment $\mathrm{Fe}_{\mathrm{h}-\mathrm{lab}}$ I $\left(\mathrm{HFO}+\mathrm{Fe}_{\mathrm{h}-\mathrm{lab}}\right)$ composition with pore-fluid $\delta^{56} \mathrm{Fe}$. The sample depth of data is represented by the grayscale. The $\mathrm{Fe}_{\mathrm{h}-\mathrm{lab}}$ l $\left(\mathrm{HFO}+\mathrm{Fe}_{\text {h- }}\right)$ ratio provides an estimate of the relative enrichment of highly labile Fe phases in the reactive sedimentary pool driven by the extent of redox recycling of $\mathrm{Fe}$ during early diagenesis. The published $\mathrm{Fe}_{\text {h-lab }} /\left(\mathrm{HFO}+\mathrm{Fe}_{\mathrm{h}-\mathrm{aab}}\right)$ composition of riverbed sediments provides an estimate of the end-member composition of the reactive $\mathrm{Fe}$ pool prior to early diagenesis. The contrast between the $\mathrm{Fe}_{\mathrm{h}-\mathrm{lab}} /\left(\mathrm{HFO}+\mathrm{Fe}_{\mathrm{h}-\mathrm{lab}}\right)$ ratio of the Eel River shelf and Crozet region is attributed to the much greater supply of reactive organic carbon to the Eel River shelf, which enhances the redox recycling of Fe. The slight increase in $\mathrm{Fe}_{\mathrm{h}-\mathrm{lab}} /\left(\mathrm{HFO}+\mathrm{Fe}_{\mathrm{h}-\mathrm{lab}}\right)$ ratio at M10 (0-8 cmbsf) is attributed to episodic organic carbon inputs to the surface sediments at this site (Pollard et al., 2009), and to a turbidite layer at M6 (15-20 cmbsf; Marsh et al., 2007). 
burn for their assistance with geochemical analyses. The authors wish to express their sincere thanks to J. McManus for stimulating discussion. Further, we thank Clark Johnson and Simon Poulton for their insightful reviews.

\section{REFERENCES CITED}

Aller, R.C., 1990, Bioturbation and manganese cycling in hemipelagic sediments: Philosophical Transactions of the Royal Society of London, Series A: Mathematical and Physical Sciences, v. 331, p. 51-68, doi: 10.1098/rsta.1990.0056.

Anbar, A.D., and Rouxel, O., 2007, Metal stable isotopes in paleoceanography: Annual Review of Earth and Planetary Sciences, v. 35, p. 717-746, doi: 10.1146/annurev.earth.34.031405.125029.

Beard, B.L., Johnson, C.M., Cox, L., Sun, H., Nealson, K.H., and Aguilar, C., 1999, Iron isotope biosignatures: Science, v. 285, p. 1889-1892, doi: $10.1126 /$ science.285.5435.1889

Beard, B.L., Johnson, C.M., Von Damm, K.L., and Poulson, R.L., 2003, Iron isotope constraints on Fe cycling and mass balance in oxygenated Earth oceans: Geology, v. 31, p. 629-632, doi: 10.1130/0091-7613(2003)031<0629:IICOFC $>2.0 . \mathrm{CO} ; 2$.

Berelson, W., McManus, J., Coale, K., Johnson, K., Burdige, D., Kilgore, T., Colodner, D., Chavez, F., Kudela, R., and Boucher, J., 2003, A time series of benthic flux measurements from Monterey Bay, CA: Continental Shelf Research, v. 23, p. 457, doi: 10.1016/S0278-4343(03)00009-8.

Bergquist, B.A., and Boyle, E.A., 2006, Iron isotopes in the Amazon River system: Weathering and transport signatures: Earth and Planetary Science Letters, v. 248, p. 54-68, doi: 10.1016/j. eps1.2006.05.004.

Brantley, S.L., Liermann, L.J., Guynn, R.L., Anbar, A., Icopini, G.A., and Barling, J., 2004, Fe isotopic fractionation during mineral dissolution with and without bacteria: Geochimica et Cosmochimica Acta, v. 68, p. 3189 , doi: $10.1016 /$ j. gca.2004.01.023.

Canfield, D.E., Thamdrup, B., and Hansen, J.W., 1993, The anaerobic degradation of organic matter in Danish coastal sediments: Iron reduction, manganese reduction, and sulfate reduction: Geochimica et Cosmochimica Acta, v. 57 , no. 16, p. 3867-3883.

Crosby, H.A., Roden, E.E., Johnson, C.M., and Beard, B.L., 2007, The mechanisms of iron isotope fractionation produced during dissimilatory Fe(III) reduction by Shewanella putrefaciens and Geobacter sulfurreducens: Geobiology, v. 5, p. 169189, doi: 10.1111/j.1472-4669.2007.00103.x.

Dideriksen, K., Baker, J.A., and Stipp, S.L.S., 2008, $\mathrm{Fe}$ isotope fractionation between inorganic aqueous $\mathrm{Fe}(\mathrm{III})$ and a Fe siderophore complex: Mineralogical Magazine, v. 72, p. 313-316, doi: 10.1180/minmag.2008.072.1.313.

Elrod, V.A., Berelson, W.M., Coale, K.H., and Johnson, K.S., 2004, The flux of iron from continental shelf sediments: A missing source for global budgets: Geophysical Re- search Letters, v. 31, article no. L12307, doi: 10.1029/2004GL020216.

Froelich, P.N., Klinkhammer, G.P., Bender, M.L., Luedtke, N.A., Heath, G.R., Cullen, D., Dauphin, P., Hammond, D., Hartman, B., and Maynard, V., 1979, Early oxidation of organic matter in pelagic sediments of the eastern equatorial Atlantic: Suboxic diagenesis: Geochimica et Cosmochimica Acta, v. 43, p. 10751090, doi: 10.1016/0016-7037(79)90095-4.

Gehlen, M., Rabouille, C., Ezat, U., and GuidiGuilvard, L.D., 1997, Drastic changes in deepsea sediment porewater composition induced by episodic input of organic matter: Limnology and Oceanography, v. 42, p. 980-986.

Haeckel, M., König, I., Riech, V., Weber, M.E., and Suess, E., 2001, Pore water profiles and numerical modelling of biogeochemical processes in Peru Basin deep-sea sediments: Deep-Sea Research, Part II: Topical Studies in Oceanography, v. 48, p. 3713-3736, doi: 10.1016/S09670645(01)00064-9.

Icopini, G.A., Anbar, A.D., Ruebush, S.S., Tien, M., and Brantley, S.L., 2004, Iron isotope fractionation during microbial reduction of iron: The importance of adsorption: Geology, v. 32, p. 205-208, doi: 10.1130/G20184.1.

Johnson, C.M., Beard, B.L., and Roden, E.E., 2008, The iron isotope fingerprints of redox and biogeochemical cycling in modern and ancient Earth: Annual Review of Earth and Planetary Sciences, v. 36, p. 457-493, doi: 10.1146/annurev.earth.36.031207.124139.

King, S.L., Froelich, P.N., and Jahnke, R.A., 2000, Early diagenesis of germanium in sediments of the Antarctic South Atlantic: In search of the missing Ge sink: Geochimica et Cosmochimica Acta, v. 64, p. 1375, doi: 10.1016/S00167037(99)00406-8.

Lam, P.J., Bishop, J.K.B., Henning, C.C., Marcus, M.A., Waychunas, G.A., and Fung, I.Y., 2006, Wintertime phytoplankton bloom in the subarctic Pacific supported by continental margin iron: Global Biogeochemical Cycles, v. 20, no. 1, p. GB1006, doi: 10.1029/2005GB002557.

Luther, G.W., III, Kostka, J.E., Church, T.M., Sulzberger, B., and Stumm, W., 1992, Seasonal iron cycling in the salt-marsh sedimentary environment: The importance of ligand complexes with $\mathrm{Fe}$ (II) and $\mathrm{Fe}$ (III) in the dissolution of $\mathrm{Fe}(\mathrm{III})$ minerals and pyrite, respectively: Marine Chemistry, v. 40, p. 81-103, doi: 10.1016/03044203(92)90049-G.

Marsh, R., Mills, R.A., Green, D.R.H., Salter, I., and Taylor, S., 2007, Controls on sediment geochemistry in the Crozet region: Deep-Sea Research, Part II: Topical Studies in Oceanography, v. 54, p. 2260, doi: 10.1016/j.dsr2.2007.06.004.

Martin, J.H., 1990, Glacial-interglacial $\mathrm{CO}_{2}$ change: The iron hypothesis: Paleoceanography, v. 5, p. 1-13, doi: 10.1029/PA005i001p00001.

Martin, J.H., Fitzwater, S.E., and Gordon, R.M., 1990, Iron deficiency limits phytoplankton growth in Antarctic waters: Global Biogeo- chemical Cycles, v. 4, p. 5-12, doi: 10.1029/ GB004i001p00005.

McManus, J., Berelson, W.M., Coale, K.H., Johnson, K.S., and Kilgore, T.E., 1997, Phosphorus regeneration in continental margin sediments: Geochimica et Cosmochimica Acta, v. 61, p. 2891, doi: 10.1016/S0016-7037(97)00138-5.

Nishioka, J., Ono, T., Saito, H., Nakatsuka, T., Takeda, S., Yoshimura, T., Suzuki, K., Kuma, K., Nakabayashi, S., Tsumune, D., Mitsudera, H., Johnson, K.W., and Tsuda, A., 2007, Iron supply to the western subarctic Pacific: Importance of iron export from the Sea of Okhotsk: Journal of Geophysical Research, v. 112, p. C10012, doi: 10.1029/2006JC004055.

Pollard, T.R., and 33 others, 2009, Southern Ocean deep-water carbon export enhanced by natural iron fertilization: Nature, v. 457, p. 577-580.

Poulton, S.W., and Canfield, D.E., 2005, Development of a sequential extraction procedure for iron: Implications for iron partitioning in continentally derived particulates: Chemical Geology, v. 214, p. 209, doi: 10.1016/j.chemgeo.2004.09.003.

Rouxel, O.J., Bekker, A., and Edwards, K.J., 2005, Iron isotope constraints on the Archean and Paleoproterozoic ocean redox state: Science, v. 307, p. 1088-1091, doi: 10.1126/science.1105692.

Severmann, S., Johnson, C.M., Beard, B.L., and McManus, J., 2006, The effect of early diagenesis on the Fe isotope compositions of porewaters and authigenic minerals in continental margin sediments: Geochimica et Cosmochimica Acta, v. 70, p. 2006-2022, doi: 10.1016/j.gca.2006.01.007.

Severmann, S., Lyons, T.W., Anbar, A., McManus, J., and Gordon, G., 2008, Modern iron isotope perspective on the benthic iron shuttle and the redox evolution of ancient oceans: Geology, v. 36, p. 487-490, doi: 10.1130/G24670A.1.

Sommerfield, C.K., and Nittrouer, C.A., 1999, Modern accumulation rates and a sediment budget for the Eel shelf: A flood-dominated depositional environment: Marine Geology, v. 154, p. 227241, doi: 10.1016/S0025-3227(98)00115-7.

van der Zee, C., Roberts, D.R., Rancourt, D.G., and Slomp, C.P., 2003, Nanogoethite is the dominant reactive oxyhydroxide phase in lake and marine sediments: Geology, v. 31, p. 993-996 doi: 10.1130/G19924.1

Vargas, M., Kashefi, K., Blunt-Harris, E.L., and Lovley, D.R., 1998, Microbiological evidence for $\mathrm{Fe}(\mathrm{III})$ reduction on early Earth: Nature, v. 395, p. 65-67, doi: 10.1038/25720.

Yamaguchi, K.E., Johnson, C.M., Beard, B.L., and Ohmoto, H., 2005, Biogeochemical cycling of iron in the Archean-Paleoproterozoic Earth: Constraints from iron isotope variations in sedimentary rocks from the Kaapvaal and Pilbara cratons: Chemical Geology, v. 218, p. 135-169.

Manuscript received 8 December 2008

Revised manuscript received 31 March 2009

Manuscript accepted 7 April 2009

Printed in USA 